\title{
ANALISIS PENERIMAAN DAN BAGI HASIL PAJAK KENDARAAN BERMOTOR PADA DINAS PENDAPATAN DAERAH PROVINSI SULAWESI UTARA
}

\author{
Jordi Theo ${ }^{1}$, Sifrid Pangemanan ${ }^{2}$, Stanley Kho Walandouw ${ }^{3}$ \\ ${ }^{123}$ Jurusan Akuntansi, Fakultas Ekonomi dan Bisnis, Universitas Sam Ratulangi, J1. Kampus Bahu, Manado, \\ 95115, Indonesia \\ E-mail: jt.jorditheo@gmail.com
}

\begin{abstract}
Tax is one of the state and regional revenue that must be optimized to support the project in the framework of tourism. Motor Vehicle Tax is one type of Provincial Tax which will result from its receipt will also be submitted to Regency/City with profit sharing system. The results of the Motor Vehicle Tax Receipts shall be allocated at least 10\% (percent percent) for the improvement of road infrastructure and improvements to public transportation modes. This study aims to determine and analyze Income from Motor Vehicle Tax at North Sulawesi Revenue Service Office. This research uses descriptive research method. The result of research shows that realization of profit sharing of motor vehicle tax in North Sulawesi province has been in accordance with Government Regulation and Distribution of Motorized Tax Realization in 2017 has exceeded predetermined target of provincial tax sector is high. Keywords: Taxes, Motor Vehicle Taxes, Profit Sharing
\end{abstract}

\section{PENDAHULUAN}

Pembangunan ialah suatu tugas mewujudkan tujuan nasional yang berkesinambungan. Untuk meningkatkan kesejahtraan rayak memerlukan peranan dan aspek pemerintah. Berkaca dari pengembangan saat ini menuntut dari setiap daerah untuk membangun daerahnya sendiri dan dengan didukung kebijakan otonomi daerah yang diberlakukan untuk pemerintah pusat agar perintah daerah lebih mandiri dalam menata daerahnya, ini juga dapat mengingkatkan pendapatan ekonomi rakyat. Meskipun diberlakukan kebijakan otonom daerah oleh pemerintah pusat ini kerap menjadi masalah yang cukup sulit dihapi oleh pemerintah daerah karna terbatasnya jumlah dana, terutama bagi daerah yang kurang berkembang. Keuangan ialah suatu alat untuk mengukur kekuatan daerah.

Pajak Daerah dibagi menjadi dua, yaitu: Pajak Provinsi dan Pajak Kabupaten/ Kota. PKB ialah merupakan salah satu pendapatan daerah yang kompeten, dimana dapat memberikan sumbangsi yang tinggi kepada daerah. Karena kendaraan bermotor dapat membantu kelancaran transportasi untuk kegiatan rakyat. Ditambah semakin meningkatnya volume kendaraan bermotor, pajak yang akan dikenakan pada pemilik akan semaking tinggi. Dalam hal ini dapat meningkatan pendapatan penerimaan daerah tertentu dari sektor Pajak Kendaraan Bermotor. Supaya tidak terjadi penyalahgunaan dalam hal pengalokasian penghasilan daerah, maka harus ada pengawasan. Hasil Penerimaan PKB paling sedikit dialokasikan $10 \%$ untuk meningkatkan sarana dan prasarana jalan serta serta meningkatkan modal transportasi umum. Dalam pemungutan PKB daerah Sulut, "No. 7 Thn 2011 tentang Pajak Daerah dan Peraturan Gubernur Provinsi Sulawesi Utara No. 3 Thn 2010 tentang penetapan alokasi sementara bagi hasil pajak provinsi kepada pemerintah kabupaten atau kota se-provinsi Sulawesi Utara dari Pajak Kendaraan Bermotor". Tujuan penelitian ini yaitu mencari tahu dan menganalisis Alokasi Dana Bagi Hasil terhadap Penerimaan PKB Daerah Provinsi SULUT. 


\section{TINJAUAN PUSTAKA}

Definisi Akuntansi. Akuntansi Menurut Pontoh (2013:1) ialah, "sebuah system informasi yang mengukur aktivitas bisnis, pemrosesan data menjadi laporan keuangan, dan mengkomunikasikan hasilnya pada para pengambil keputusan". Sedangkan menurut Reeve, Warren, Fess, (2012:9) yaitu, "suatu sistem informasi yang menyediakan laporan untuk pemangku kepentingan mengenai aktivitas dan kondisi ekonomi perusahaan". Beberapa kutipan pendapat dari ahli mengenai definisi akuntansi, yaitu sebagai berikut:

a. American Institute of Certified Public Accountant: "Akuntansi adalah seni pencatatan, penggolongan, dan peringkasan transaksi dari kejadian yang bersifat keuangan dengan cara yang berdaya guna dan dalam bentuk satuan uang, dan penginterpretasian hasil proses tersebut".

b. American Accounting Association: Proses mengindentifikasikan, mengukur dan melaporkan inbformasi ekonomi, untuk memungkinkan adanya penilaian dan keputusan yang jelas dan tegas bagi mereka yang menggunakan informasi tersebut. Niswonger, Fess dan Warren yang diterjemahkan oleh Marianus Sinaga dalam Puspitawati dan Anggadini (2011:1) menyatakan bahwa:

American Accounting Association: "Akuntansi merupakan proses mengenali, mengukur dan mengkomunikasikan informasi ekonomi untuk memperoleh pertimbangan dan keputusan yang tepat oleh pemakai informasi bersangkutan".

Dari tiga pengertian di atas, dapat diambil kesimpulan yaitu:

1. Bahwa akuntansi yaitu suatu proses yang terdiri dari peng-identifikasi, pengukuran dan pelaporan informasi ekonomi.

2. Informasi tersebut diharapkan bisa bermanfaat dalam suatu penilaian dan pengambilan keputusan.

Aktivitas akuntansi meliputi :

1. Mengindentifikasikan dan mengukur data yang relevan untuk suatu pengambilan keputusan.

2. Pemrosesan dan atau menganlisa data-data yang relavan.

3. Mengkomunikasikan informasi yang dihsilkan kepada pihak pemakai akuntansi.

Pengertian Pajak Daerah. Menurut UU Nomor 28 Thn. 2009 tentang pajak daerah dan retribusi daerah, yang dimaksud dengan pajak daerah ialah:

"Kontribusi WP kepada daerah yang terutang oleh orang pribadi atau badan yang bersifat memaksa berdasarkan undang-undang dengan tidak mendapatkan imbalan secara langsung dan digunakan untuk keperluan daerah bagi sebesar-besarnya kemakmuran rakyat". Sedangkan menurut Eryandi (2011:39) yaitu, "salah satu sumber pendapatan yang diandalkan oleh daerah baik daerah provinsi maupun kabupaten atau kota".

\section{Sistem Pemungutan Pajak Daerah}

1. Sistem Official Assesment, "suatu system pemungutan yang memberi wewenang kepada pemerintah ( Fiskus ) untuk menentukan besarnya pajak yang terutang oleh wajib pajak".

2. Sistem Sef Assesment yaitu suatu, "system pemungutan pajak yang memberi wewenang kepada wajib pajak untuk menentukan sendiri besarnya pajak terutang".

3. Sistem With Holding, ialah suatu system pemungutan pajak yang memberi wewenang kepada pihak ketiga (bukan fiskus dan bukan wajib pajak yang bersangkutan) untuk menentukan besarnya pajak yang terutang ada pihak ketiga, pihak selain fiscal dan wajib pajak. 
Pajak Kendaraan Bermotor. Pemungutan PKB berdasarkan, Undang-Undang Nomor 28 Tahun 2009 Pajak Kendaraan Bermotor ialah pajak atas kepemilikan dan atau penguasaan kendaraan bermotor, yang semua kendaraan beroda beserta gandengannya yang digunakan disemua jenis jalan darat, dan digerakkan oleh peralatan teknik berupa motor atau peralatan lainnya yang berfungsi untuk mengubah suatu sumberdaya energy tertentu menjadi tenaga gerak kendaraan bermotor yang bersangkutan, termasuk alat berat dan alat besar yang dalam operasinya menggunakan roda dan motor dan tidak melekat secara permanen serta kendaraan bermotor yang diopersikan didalam air.

\section{Dasar Perhitungan dan Tarif Perhitungan Kendraaan Bermotor}

a. Dasar Perhitungan PKB. Besarnya pokok pajak kendaraan bermotor yang terhutang dihitung dengan cara dilakukan dengan mengalihkan tarif pajak dengan dasar pengenaan pajak. perhitungan PKB adalah se umumnya:

Pajak Terhutang $=$ Tarif Pajak $*$ Dasar Pengenaan Pajak

$$
=\text { Tarif Pajak } *(\mathrm{NJKB} * \text { Bobot })
$$

b. Tarif Pajak Kendaraan Bermotor. Ditetapkan seragam diseluruh Indonesia dan diatur oleh Peraturan Pemerintah dengan tujuan tidak terjadi pemanfaatan tarif pajak yang lebih tinggi didaerah tertentu. Tarif pajak PKB adalah sebagai berikut :

1. Tarif Pajak Kendaraan Bermotor ditetapkan paling tinggi 10\% (sepuluh persen) dalam perincian :

a. Tarif pajak Kendaraan Bermotor pribadi kepemilikan pertama ditetapkan paling tinggi sebesar $2 \%$ (dua persen).

b. Untuk Kendaraan Bermotor pribadi kepemilikan kedua dan seterusnya tarif dapat ditetapkan secara progresif paling tinggi sebesar $10 \%$.

2. Punggutan PKB angkutan umum, ambulans, pemadam kebakaran, social keagamaan, lembaga social dan keagamaan, Pemerintah / TNI / POLRI, Pemerintah Daerah, dan Kendaraan lain yang ditetapkan dengan Peraturan Daerah, dan Kendaraan lain yang ditetapkan paling rendah $0,5 \%$ dan paling tinggi sebesar $2 \%$, Tarif Pajak Kendaraan Bermotor alat besar ditetapkan paling rendah $0,1 \%$ dan paling tinggi $0,2 \%$.

3. Tarif BBNKB ditetapkan paling tinggi masing - masing yaitu sebagai berikut:

a. Penyetoran pertama ditetapkan $20 \%$.

b. Penyetoran kedua dan seterusnya ditetapkan $1 \%$ (satu persen).

Bagi Hasil Pajak Provinsi. Menurut Perda Nomor 8 Tahun 2013 Bagi Hasil Penerimaan Pajak Pada Dinas Pendapatan Provinsi terdiri dari :

1. Bagi Hasil Penerimaan PKB

2. Bagi Hasil Penerimaan BBNKB

3. Bagi Hasil Penerimaan PBBKB

4. Bagi Hasil Penerimaan PAP

5. Bagi Hasil Penerimaan Pajak Rokok.

\section{Alokasi Bagi Hasil Penerimaan Pajak Kendaraan Bermotor}

1. Hasil Penerimaan Pajak Kendaraan Bermotor diserahkan kepada :

a. Pemerintah Provinsi sebesar $70 \%$.

b. Pemerintah Kabupaten/Kota sebesar $30 \%$ setelah dipotong insentif.

2. Pembagian Hasil Penerimaan PKB kepada Pemerintah Kabupaten atau Kota sebesar :

a. $40 \%$ berdasarkan pemerataan.

b. $60 \%$ berdasarkan potensi atau realisasi penerimaan pajak pada masing-masing Kabupaten/Kota. 
Penelitian Terdahulu. Putra (2014) meneliti, Analisis Kontribusi Dan Potensi Pajak Kendaraan Bermotor Untuk Meningkatkan PAD Provinsi Sumatera Barat, dengan teknik analisis data yang digunakan dalam penelitian ini adalah analisis deskriptif yang menggunakan analisis kontribusi dan analisis potensial. Hasil penelitian menunjukkan bahwa kontribusi Pajak Kendaraan Bermotor untuk meningkatkan pendapatan daerah asli Provinsi Sumatera Barat dari tahun 2009-2013 rata-rata berkisar antara 27\% hingga 31\% termasuk dalam kriteria sedang, untuk kendaraan bermotor Pajak Pengadaan di provinsi Sumatera Barat pada 2009-2013 menunjukkan peningkatan yang signifikan. Magistya (2018) meneliti, Pemanfaatan Dana Bagi Hasil Pajak Kendaraan Bermotor Di Kota Bandar Lampung, dengan metode yang digunakan dalam penelitian ini adalah pendekatan deskriptif kualitatif dan Hasil Penelitian menunjukan bahwa Pemanfaatan dan abagi hasil pajak kendaraan bermotor di Kota Bandar Lampung didalam UU No. 28 Tahun 2009 pada pasal 8 ayat (5) yang menyebutkan bahwa hasil penerimaan PKB sebesar paling sedikit 10\%, termasuk yang dibagi hasilkan kepada Kabupaten atau kota dan dialokasikanu ntuk pembangunan dan atau pemeliharaanjalan, mengenai pemanfaatan dana bagi hasil pajak kendaraan bermotor dari triwulan pertama dan kedua mengalami peningkatan.

\section{METODE PENELITIAN}

Jenis Penelitian. Metode analisis deskriptif yaitu metode yang digunakan untuk menganalisis data dengan cara mendeskripsikan atau menggambarkan data yang telah terkumpul sebagaimana adanya tanpa maksud membuat kesimpulan yang berlaku untuk umum dan generalisasi (Sugiyono, 2013).

Tempat Dan Waktu Penelitian. Lokasi penelitian dilakukan pada DISPENDA Provinsi Sulut bertempat di Jln. 17 Agustus Nomor 67 Manado, waktu pelaksanaan Januari 2018.

Prosedur Penelitian. Proses Penelitian dilalakukan berikut:

1. Mencari data yang berkaitan dengan judul penelitian. Penulis berkunjug langsung di DISPENDA Prov SULUT, bertanya-jawab dengan pihak kantor pada bagian pengurusan pajak dan mengumpulkan informasi yang berkaitan dengan pemungutan PKB.

2. Memeperoleh keternagan dari data yang akan diteliti dan melihat masalah-masalah yang terdapat didalamnya.

3. Mengelolah dan membahas Kontribusi PKB tentang Pajak Daerah Propinsi SULUT pada DISPENDA Provinsi Sulawesi Utara.

4. Menarik kesimpulan dan memberikan saran.

Metode Pengumpulan Data. Dalam rangka pengambilan data atau informasi yang berhubungan dengan penelitian ini maka dilakukan teknik pengumpulan data sebagai berikut:

1. Penelitian diperpustakaan, Penelitian ini dilakukan untuk mendapatkan landasan teori untuk mendukung data yang diperoleh selama penelitian. Data ini diperoleh dari buku buku serta referensi.

2. Penelitian Lapangan, Penelitian ini dilakukan secara peninjauan langsung ke DISPENDA Prov SULUT untuk mendapatkan informasi yang diperlukan dengan teknik sebagai berikut:

a. Dokumentasi. Suatu pengumpulan dokumen-dukumen yang terkait dalam objek peneliti dan masalah yang terdpat dalam laporan hasil penerimaan pajak daerah tahun 2017 dan keputusan yang dilakukan.

b. Inquires. Untuk mendapatkan penjelasan tentang latar belakang penelitian seperti struktur organisasi dan sejarah. Dari objek yang akan diteliti berserta informasi lainnya yang terkait dengan penelitian. 
c. Diskusi. Satu teknik pegumpulan data yang bertatap muka secara langsung dengan bagian tata usaha dan staf DISPENDA Provinsi Sulut dengan cara tanya jawab langsung. Mengenai pengambilan keputusan dalam realisasi penerimaan PKB

Metode Analisis. Metode yang digunakan dalam penelitian ini ialah metode analisis deskriptif ialah metode pembahasan permasalahan yang sifatnya menguraikan, menggambarkan, membandingkan, dan menerangkan suatu data atau keadaan yang sedemikian rupa sehingga dapat ditarik kesimpulannya untuk mencapai tujuan penelitian yang diinginkan.

\section{HASIL PENELITIAN DAN PEMBAHASAN}

\subsection{Hasil Penelitian}

Penerimaan Pajak Kedaraan Bermotor Provinsi Sulawesi Utara. Penerimaan Pajak Kendaraan Bermotor (PKB) merupakan pajak yang memiliki kontribusi besar dalam Pendapatan Asli Daerah Provinsi Sulawesi Utara. Laporan Target dan Realisasi Pajak Kendaraan Bermotor menggambarkan capaian penerimaan yang diterima Pajak Kendaraan Bermotor. Tabel 1 dibawah ini menguraikan Target dan Realisasi Pajak Kendaraan Bermotor tahun 2017.

Tabel 1. Penerimaan PKB Provinsi Sulawesi Utara Thn. 2017

\begin{tabular}{clrrr}
\hline No & \multicolumn{1}{c}{ Kabupaten } & \multicolumn{1}{c}{ Target } & \multicolumn{1}{c}{ Realisasi } & \multicolumn{1}{c}{ Capaian } \\
\hline 1 & Manado & 140.286 .783 .336 & 144.358 .958 .860 & $102,90 \%$ \\
2 & Tondano & 23.255 .550 .100 & 25.079 .063 .852 & $107,84 \%$ \\
3 & Bitung & 28.017 .039 .500 & 28.133 .896 .103 & $100,42 \%$ \\
4 & Tahuna & 4.402 .262 .040 & 4.788 .803 .405 & $108,78 \%$ \\
5 & Kotamobagu & 13.684 .893 .920 & 13.508 .916 .519 & $98,71 \%$ \\
6 & Amurang & 12.101 .148 .200 & 13.196 .688 .887 & $109,05 \%$ \\
7 & Airmadidi & 26.550 .411 .780 & 27.747 .500 .246 & $104,71 \%$ \\
8 & Tomohon & 13.358 .917 .000 & 27.152 .421 .745 & $102,52 \%$ \\
9 & Minahasa Tenggara & 6.136 .233 .000 & 6.297 .107 .431 & $102,62 \%$ \\
10 & Bolaang Mongondow & 9.625 .534 .700 & 9.871 .407 .490 & $102,55 \%$ \\
11 & Bolaang Mongondow Utara & 2.847 .225 .640 & 2.796 .284 .600 & $98,21 \%$ \\
12 & Bolaang Mongondow Timur & 3.150 .137 .700 & 3.073 .806 .800 & $97,58 \%$ \\
13 & Bolaang Mongondow Selatan & 2.061 .672 .140 & 2.029 .976 .875 & $98,46 \%$ \\
14 & Talaud & 1.419 .636 .440 & 1.431 .722 .640 & $100,85 \%$ \\
15 & Siau Tagulandang Biaro & 959.894 .504 & 1.009 .410 .585 & $105,16 \%$ \\
\hline \multicolumn{2}{c}{ Jumlah } & $\mathbf{2 8 7 . 8 5 7 . 3 4 0 . 0 0 0}$ & $\mathbf{2 9 7 . 0 1 9 . 6 3 2 . 3 3 8}$ & $\mathbf{1 0 3 , 1 8 \%}$ \\
\hline
\end{tabular}

Sumber: DISPENDA, 2017

Tabel 1 menunjukan besaran penerimaan PKB tahun 2017. Dimana terlihat dimana hanya tiga Kota / kabupaten yang tidak mencapai $100 \%$ reaslisasi yaitu Kabupatn Bolaang Mongondow Timur sebesar 97,58\%, Bolaang Mongondow Selatan 98,46\%, Bolaang Mongondow Utara 98,21\% dan Kotamobagu 98,71\%. Walaupun demikian pencapaian secara keseluruhan Pajak Kendaraan bermotor memeiliki capaian 103,18\%.

Alokasi Bagi Hasil Pajak Kendaraan Bermotor Provinsi Sulawesi Utara. Alokasi Bagi hasil PKB yang berlaku di Provinsi SULUT diberlakukan menurut Perda Nomor 8 Tahun 2013 yaitu:

1. Hasil Penerimaan Pajak Kendaraan Bermotor diserahkan kepada : (a) Pemerintah Provinsi sebesar 70\%.; dan (b) Pemerintah Kabupaten atau Kota sebesar 30\% setelah dipotong insentif. 
2. Pembagian Penerimaan PKB kepada Pemerintah Kab/Kota yaitu : (a) $40 \%$ berdasarkan pemerataan; dan (b) $60 \%$ berdasarkan potensi atau realisasi penerimaan pajak pada masing-masing Kabupaten atau Kota.

\subsection{Pembahasan}

Berdasarkan Uraian diatas serta data penerimaan Pajak Kendaraan Bermotor Provinsi Sulawesi Utara pada table 4.2, maka Pajak Kendaraan Bermotor ProvinsiSulawesi Utara tahun 2017 periode januari-desember dapat dirumuskan sebagai berikut :

\section{( Periode Januari - Desember)}

Realisasi PKB selama Tahun 2017

Insentif 3\% x Rp. 297.019.632.338

Pajak Bersih

$$
\begin{array}{ll}
= & \text { Rp. } 297.019 .632 .338 \\
= & \text { Rp. 8.910.588.970 } \\
= & \text { Rp. } 288.109 .043 .368
\end{array}
$$

\section{Pembagian kepada Pemerintah Provinsi dan Kabupaten/Kota : \\ o Provinsi 70\% x Rp. 288.109.043.368 $=$ Rp. 201.676.330.358 \\ o Kab/Kota $30 \%$ x Rp. 288.109.043.368 $=$ Rp. 86.432.713.010}

\section{Pembagian kepadaKabupaten/Kota :}

o Berdasarkan Pemerataan Kabupaten atau Kota sebesar $40 \%$

$\begin{array}{lll}40 \% \text { x Rp. 86.432.713.010 } & = & \text { Rp. } 34.573 .085 .204 \\ \text { Rata-Rata (15) } & = & \text { Rp. 34.573.085.204 } \\ & = & \text { Rp. } 2.304 .872 .346\end{array}$

o $\quad$ BerdasarkanPotensi Daerah sebesar 60\%

$60 \%$ x Rp. 86.432.713.010 = Rp. 51.859.627.806

Perhitungan diatas menunjukan bagi hasil untuk Provinsi sebesar Rp. 201.676.330.358 yang didapat dari 70\% dari total penerimaan Pajak Kendaraan Bermotor (PKB) sedangkan untuk kota/kabupaten Rp. 86.432.713.010 sebesar 30\% dari total penerimaan PKB. Untuk pemerataan masing-masing kabupaten sebesar $40 \%$ yaitus ebesar Rp. 34.573.085.204, diperoleh rata-rata untuk 15 kabupaten/kota sebesar Rp. 2.304.872.346. Sedangkan untuk Potensi daerah memiliki besaran presentase $60 \%$. Dari total pembagian untuk kabupaten/kota yaitu Rp. 86.432.713.010 menghasilkan total pembagian Rp. 51.859.627.806.

\section{KESIMPULAN DAN SARAN}

\subsection{Kesimpulan}

Dari pembahasan yang dilakukan peneliti tentang menganalisis realisasi penerimaan biaya balik nama kendaraan bermotor maka dapat disimpulkan sebagai berikut:

1. Realisasi Bagi Hasil PKB pada Provinsi SULUT telah sama dengan Ketentuan atau Peraturan Daerah dan Ketentuan Gubernur.

2. Jumlah Realisasi Pajak Kendaraan Bermotor Pada Tahun 2017 berhasil melampaui target yang telah ditetapkan sebelumnya sehingga kontribusi yang diberikan kepada Pendapatan Asli Daerah dari sektor pajak provinsi mengalami peningkatan.

\subsection{Saran}

Dalam penelitian yang dilakukan dan hasil kesimpulan yang telah didapat, maka saran-saran yang diberikan sebagai berikut:

1. Kepada Dinas Pendapatan Daerah Provinsi Sulawesi Utara perlu melakukan perubahanperubahan didalam untuk cara melayani pembayaran pajak atau perubahan cara dari sistem yang lainnya, serta dalam hal penentuan target penerimaan pajak harus optimal dan efisien. 
2. Untuk peneliti selanjutnya dapat memperhatikan kekuranagan yang terdapat dalam penelitian ini, diharapkan ada penelitian lainnya yang dapat mempunyai topik sama di kemudian hari untuk memperbaiki kekuranagan peneliti sebelumnya.

Adapun saran-saran untuk penelitian selanjtnya yakni:

1. Agar dapat menambah tempat penelitian yaitu Dispenda Minahasa Tenggara dan Dispenda Provinsi Sulawesi Utara.

2. Disarankan bagi peneliti selanjutnya dapat menambahkan faktor-foktor yang belum terdapat didalam penelitian serupa: BBNKB, PBBKB, dll.

\section{DAFTAR PUSTAKA}

Eryandi G., 2011. Analisis Efektivitas Pemungutan Pajak Kendaraan Bermotor Dan Bea Balik Nama Kendaraan Bermotor Dalam Meningkatkan Pendapatan Asli Daerah (PAD) Di Provinsi Bengkulu. Bengkulu.

Mardiasmo, 2013. Perpajakan Edisi Revisi. Edisi Ketiga Belas. Penerbit Andi, Yogyakarta.

Pemerintah Provinsi Sulawesi Utara, 2010. Peraturan Daerah No. 7 Tahun 2011 Pajak Daerah.

Pemerintah Provinsi Sulawesi Utara, 2011. Peraturan Daerah No. 7 Tahun 2011 Pajak Daerah.

Pontoh W., 2013. Akuntansi Konsep dan Aplikasi.Halaman Moeka, Jakarta.

Puspitawati dan Anggadini, 2011.Sistem Informasi Akuntansi. Graha Ilmu, Yogyakarta.

Putra Adhe Adhardi. (2014)., Analisis Kontribusi dan Potensi Pajak Kendaraan Bermotor untuk Meningkatkan Pendapatan Asli Daerah Provinsi Sumatera Barata. Universitas Bung Hatta. Padang

Reeve, Warren JM, Fees CS, Philip E., 2012.Pengantar Akuntansi. Salemba Empat, Jakarta.

Republik Indonesia, 2007. Undang-Undang No. 28 Tahun 2007 tentang Perubahan Ke-3atas UU No. 6 Thn1983 Mengenai Ketentuan Umum dan Tata Cara Perpajakan.

Republik Indonesia, 2004. UU No. 32 Tahun 2004 Tentang Pemerintahan Daerah.

Republik Indonesia, 2009. UU No. 28 Thn 2009 Mengenai Pajak Daerah dan Retribusi Daerah

Sugiyono, 2013. Metode Penelitian Bisnis.Cetakan Ke-17. Alfabeta. Bandung 